\title{
Equitable Fiscal Consolidations
}

\author{
October 2016
}

\begin{abstract}
Empirical research has uncovered an equity-efficiency trade-off in alternative fiscal consolidation strategies. Spending-based adjustments are associated with more limited output losses but greater inequality than tax-based adjustments. Moreover, spending-based adjustments are less likely to be reversed, but an increase in inequality reduces the likelihood of achieving a succesful consolidation. We investigate the issue of designing a debt consolidation plan which is achieved through a reduction in public consumption and yet is equitable because temporary targeted transfers and tax reductions stabilize consumption of the poorer part of the population. This causes a limited slow-down in the pace of debt reduction because fiscal multipliers associated to the tax/transfer policies are large.
\end{abstract}

JEL Classification System: E32, E62, E63

Keywords: Fiscal Consolidation, DSGE modelling, Rule of Thumb Consumers, Fiscal Policy, Monetary Policy, Zero Lower Bound 


\section{Introduction}

Following the large increases in public debt-to-GDP ratios observed in the aftermath of the 2007 -financial crisis, the issue of fiscal consolidation, i.e. a reduction in the debt-to-GDP ratio, has come to the forefront of political debate and macroeconomic analyses (OECD 2012). In the Eurozone debt consolidation is a key concern of the Eurpean Commission, and institutional arrangements such as the Maastricht Treaty and the Stability and Growth Pact (SGP) should oblige member states to pursue a $60 \%$ debt-to-GDP ratio. The 'corrective arm' of the SGP should be activated whenever public debt exceeds $60 \%$ of GDP and the excess debt is not reduced by $5 \%$ per year on average over three years (European Commission). As a matter of fact, consolidations are a politically divisive issue, and long-term sustainability of fiscal adjustment plans cannot be taken for granted. Austerity in the Eurozone is increasingly challenged for its apparently modest effects on the debt-to-GDP ratios and for its undesirable social implications (Corsetti, 2012; Darvas and Tschekassin, 2015).

In empirical research, early enthusiasm towards the expansionary effects of public consumption contractions seems to have vanished (Perotti, 2012), but several contributions emphasize the importance of relying on expenditure cuts as

a key driver of consolidations. Nickel, Rother and Zimmermann (2010) find that major debt reductions in the EU-15 during the period 1985-2009 were mainly caused by strategies based on reduction of government consumption, whereas revenue-based consolidation efforts were less successful. The same conclusion is reached in Alesina, Favero and Giavazzi (2012), who argue that spending- 
based adjustments are associated with mild and short-lived output losses, while tax-based adjustments are associated with deep and prolonged recessions.

There is, however, another side to the coin. In fact, a growing body of empirical evidence points at the distributive implications of consolidations. Ball et al. (2013) examine the distributional effects of fiscal consolidations in a sample of 17 OECD countries over the period 1978-2009 finding that fiscal consolidation has typically raised inequality. Further, Woo et al. (2013) find that spending-based consolidations tend to worsen inequality more significantly than tax-based consolidations. Similar results are obtained in Agnello and Sousa (2014).

Another related issue concerns the sustainability of consolidations. According to a popular view adjustment programmes relying mainly on expenditure cuts rather than on tax revenue increases are less likely to be reversed (Alesina and Ardagna, 2010, 2013; Molnar, 2012). However, equitable distribution of fiscal adjustment costs is found to raise the chance of consolidation success, thus providing the "double dividend" of sustainable consolidation and enhanced social cohesion (Kaplanoglou et al., 2015).

So far, the debate on the equity-efficiency tradeoff in fiscal consolidations has tipically focussed on empirical evidence. By contrast, in this paper we investigate the issue of designing a debt consolidation plan which is achieved through a reduction in public consumption and yet is equitable.

Within the theoretical framework of DSGE models characterized by complete financial markets and optimizing households, expenditure-based fiscal consoli- 
dations are a win-win strategy that reduces steady state distortionary taxation and raises private consumption even in the short run. This latter effect obtains because, despite the output drop, a positive wealth effect is in place, driven by the expectation of permanently lower taxes. From this viewpoint, the NKDSGE model gives similar predictions to those of RBC models (see, for example, Linnemann and Schabert, 2003). Therefore, expenditure-based consolidations produce a gain without pain, as the policy entails a short-run consumption boom and a fall in labor effort.

The assumption of homogeneous and forward-looking households is at best only partly consistent with actual consumer behavior. The predicted effect of fiscal consolidations may look rather grim if one takes into account the hypotesis of Limited Asset Market Participation (LAMP henceforth) ${ }^{1}$, implying a distinction between a fraction of households who have full access to financial markets (Ricardian households, henceforth) and a fraction of households who do not participate in financial markets and just consume their current income (Rule of Thumb, RT henceforth). For these households the fiscal consolidation envisages a gain with pain if the short-run decline of output is associated to a reduction in their disposable income (Coenen, Mohr and Straub, 2008, CMS henceforth; Almeida et al., 2013). This result has been implicitly acknowledged in policy-oriented research that emphasizes the importance of pursuing "equity friendly" consolidation plans (OECD 2013; Rawdanowicz et al. 2013).

\footnotetext{
${ }^{1}$ The LAMP assumption finds considerable empirical support (Campbell and Mankiw, 1989; Fuhrer, 2000; Cowell, Karagiannaki and McKnight, 2012; Anderson, Inoue and Rossi, 2013; Iacoviello and Pavan, 2013).
} 
We investigate the contribution of fiscal and monetary policies that may stabilize consumption of RT consumers, potentially restoring the gain without pain result. When all households are Ricardian, consumption choices mainly react to the present value of future tax payments, and the selected time path for the tax reduction plan is almost irrelevant. Under LAMP a fraction of households would certainly react to tax reductions implemented in the early phase of the consolidation process, when employment falls due to nominal rigidities. In addition, an important role might be played by temporary public transfers, that would be irrelevant under the representative household assumption. Another important issue is whether such policies might indeed have a limited effect on the pace of debt consolidation due to their stimulus to output growth and therefore to fiscal revenues. Finally, monetary policy might have a powerful stabilizing effect on the consumption of constrained households if it exploited the complementarity between the consumption of Ricardian households, stimulated by the interest rate fall, and the labor income accruing to RT households.

We design a consolidation experiment where the long-run debt reduction is obtained through a temporary fall in public consumption and is associated to a permanent fall in tax rates. During the transition period we allow taxes (and public transfers) to react to the temporary drop in output. One important distinction between our work and previous contributions is that in our framework reducing public consumption is, by assumption, costly for the policymaker. This issue is typically neglected in the theoretical literature on fiscal consolidations, despite the apparent difficulties that governments meet when attempting to cut 
their expenditures. However this assumption has no direct effect on the distribution of welfare gains between the two households groups because the costs of public consumption reductions are symmetrical.

In a nutshell, our results are summarized as follows. First, we show that it is possible to both reduce public debt and boost consumption of RT households. This is obtained by allowing taxes to immediately undershoot their post-consolidation steady-state values. These "overexpansionary" fiscal policies allow to raise the disposable income of RT consumers, and yet we do not observe a significant slow down in the pace of debt reduction due to the favourable impact of consumption growth on output and government revenues. A similar result is obtained if temporary public transfers to RT households are exploited to stimulate demand. This is in sharp contrast with recent consolidation plans in advanced countries, that apparantly rely on both expenditure reductions and tax hikes (Figure 1). Our findings suggest that such a policy mix is bound to depress consumption and economic activity. In fact, this study calls for new tax/transfer policies that limit the consumption gap between Ricardian and RT households and improve the short-medium run performance of the macroeconomy.

(Figure 1 here)

Second, we find that an interest rate rule which reacts not only to inflation but also to the output gap is an effective complement to fiscal policy as a stabilization tool. In fact, the output gap target induces the Central Bank to implement a stronger interest rate cut which triggers a surge in the consumption 
of Ricardian households. This, in turn, has beneficial effects on labor incomes and on RT households' consumption. We obtain the apparently paradoxical result that such a policy allows to obtain better control of inflation, limiting deflationary pressures. Third, our analysis also highlights the risk that, without an "aggressive" fiscal policy, a large debt consolidation causes a slump so deep that the nominal interest rate is driven down to the zero lower bound. In this regard, we reach the important conclusion that transfer policies are far more effective than tax reductions. Both policies have a stabilizing impact on aggregate demand, but tax reductions also lower marginal costs and inflation, causing a downward pressure on the nominal interest rate.

One strand of literature apparently related to our study is concerned with tax reforms and with the identification of the (Ramsey optimal) financing mix between labor and capital taxation (Chamley, 1986; Judd, 1997; Guo and Lansing 1999; Greulich and Marcet, 2008; Garcia-Milà Marcet and Ventura, 2010). In fact our focus is quite different because we are mainly interested in the identification of a short-run policy mix that can enhance the sustainability of long term debt reductions. At first sight, our contribution is akin to Cogan et al. (2012) who consider the effects of fiscal consolidations in a model that accounts for LAMP and emphasizes the importance of phasing in tax reductions. Indeed there are some important differences between their work and ours. First, their definition of LAMP is such that a fraction of households do not participate in stocks and bonds markets but are allowed to hold money. Therefore, to the extent that their initial holdings of money balances are sufficiently large, 
these households may partly smooth consumption in response to a fiscal consolidation that reduces output and labor incomes. In their model intertemporal consumption optimization therefore plays an important role even for constrained households. Second, they consider a consolidation experiment which is based on the contraction of public transfers and the contemporaneous reduction of distortionary taxes. Since transfers are by assumption equally shared by all households and Ricardian consumers account for two thirds of the population, the fall in transfers has a limited effect on aggregate demand, whereas the lower tax rates unambiguously increases efficiency. The overall effect on demand is so strong that output increases even in the short run. In our analysis we abstract from apparently "easy" solutions where reducing public expenditures is costless by assumption. Further, in our experiment redistributive transfers may be a useful stabilization tool. Third, we consider the potential complementarity between fiscal and monetary policies during the transition.

The rest of the paper is organized as follows. Section 2 describes the main features of the model and the experiment implementation. Section 3 shows the results. Welfare effects of the consolidation process are discussed in section 4 . Section 5 reports some robustness analysis. Finally, section 6 concludes. 


\section{The Fiscal Consolidation Exercise}

\subsection{A Sketch of the Model}

Our model is an extended version of the NK-DSGE model developed by Smets and Wouters (2003), henceforth SW, Schmitt-Grohé and Uribe (2005), henceforth SGU and Christiano, Eichenbaum and Evans (2005), henceforth CEE. ${ }^{2}$ It embodies both real and nominal frictions. Real frictions include: monopolistic competition in goods and labour markets, internal habits in consumption, variable capacity utilization, adjustment costs in investment decisions and distortionary taxation on labor and capital incomes. As for nominal frictions, prices and wages are sticky à la Calvo (1983), with an indexation clause. ${ }^{3}$

Our model accounts for LAMP, i.e. the economy is populated by two different household types: optimizing (Ricardian) households, who hold assets, and RT households, who just consume their current income and do not own any wealth.

To implement a welfare analysis of alternative policies based on expenditure reductions we assume that government spending enters households' utility functions. In particular, preferences are defined over private individual consumption $c_{t}^{i}$, individual labor supply $h_{t}^{i}$ and real government consumption $G_{t}^{i}$,

\footnotetext{
${ }^{2}$ The full model is laid out in Appendix B.

${ }^{3} \mathrm{SW}(2003)$ argue that partial indexation scheme makes the model more robust for policy and welfare analysis with respect to a constant price setting behavior.
} 
where $i=o, r t$ refers to Ricardian and RT consumers, respectively.

$$
U_{t}^{i}=E_{0} \sum_{t=0}^{\infty} \beta^{t}\left\{\ln \left(c_{t}^{i}-b c_{t-1}^{i}\right)-\frac{\phi_{1}}{(1+\phi)}\left(h_{t}^{i}\right)^{(1+\phi)}+\xi \ln G_{t}^{i}\right\}
$$

Moreover, $b$ is the degree of internal habit formation in consumption, $\phi$ represents the inverse of Frish elasticity and $\xi$ denotes the weight of public spending in the utility function.

\section{$2.2 \quad$ Fiscal Sector}

The period government budget constraint is described as follows:

$$
G_{t}+T R_{t}+\frac{b_{t}^{g}}{\pi_{t}}=\tau_{t}^{k} \sigma_{t} K_{t}+\tau_{t}^{h} w_{t} h_{t}+\frac{b_{t+1}^{g}}{R_{t}}
$$

where $G$ define real government consumption and $T R$ denote real transfers to households, $b^{g}$ is the outstanding stock of real debt, $\tau^{h}$ and $\tau^{k}$ define tax rates on labor and capital respectively, $\sigma K$ and $w h$ respectively denote gross capital and labor incomes.

We model fiscal consolidation as a permanent reduction of the debt-to-GDP ratio via a temporary decline of the expenditure ratio. The fiscal consolidation exercise entails a transition from one initial steady state where the debt-to-GDP

ratio $b_{y}^{g *}$ is set at $70 \%$ to a new steady state where $b_{y}^{g * *}=60 \%$, in line with Coenen et al. (2008). In this experiment we assume that savings on interest payments are used to reduce taxes while the public spending ratio goes back to the initial steady state level. Therefore in the steady state associated to 
$b_{y}^{g * *}=60 \%$ tax distortions are unambiguously reduced and $y^{* *}>y^{*}$. Since we are not interested in policy-induced long-run changes in capital-labor ratios, we posit that $\left(\tau^{k * *} / \tau^{h * *}\right)=\left(\tau^{k *} / \tau^{h *}\right)$.

Our policy experiments are better characterized as multi-period plans, and the full consolidation is achieved after several years. In this regard, the Ricardian households expectation of future variations in the policy instruments drives the bulk of our results. ${ }^{4}$ The key tool used to achieve the debt reduction is a temporary reduction in public consumption. We assume that the fiscal authority follows the rule:

$$
\left(\frac{g_{y, t}}{g_{y}}\right)=\left(\frac{b_{y, t}^{g}}{b_{y}^{g * *}}\right)^{-\phi_{g}}
$$

where $g_{y}=\left(G^{*} / y^{*}\right)=\left(G^{* *} / y^{* *}\right)$ is the constant public consumption-to-GDP target ratio, $g_{y, t} \equiv\left(G_{t} / y^{* *}\right)$ and $b_{y, t}^{g} \equiv\left(b_{t}^{g} / y^{g * *}\right)$ respectively define time $t$ levels of public consumption and debt in terms of post-consolidation steadystate output.

To model the behavior of taxes during the transition phase, we assume that relative tax rates are constant throughout the transition, i.e. $\left(\tau_{t}^{k} / \tau_{t}^{h}\right)=$ $\left(\tau^{k *} / \tau^{h *}\right)=\left(\tau^{k * *} / \tau^{h * *}\right)$. Then for the sake of brevity, from now on we only refer to labor tax rate. We consider two alternative tax rules. In the first case, we assume that taxes follow a highly inertial path towards the new steady state:

$$
\tau_{t}^{h}=\left(1-\phi^{\tau}\right) \tau_{t-1}^{h}+\phi^{\tau} \tau^{h * *}
$$

\footnotetext{
${ }^{4}$ This approach is consistent with the analysis in Alesina et al. (2012) who document that fiscal consolidations in OECD countries took the form of multi-year plans.
} 
In the early stages of the consolidation experiment this allows to identify the permanent income effect of a future tax reduction, that only affects consumption choices of Ricardian households.

With the second rule we model taxes as automatic stabilizers in the spirit of Colciago et al. $(2008)^{5}$.

$$
\left(\frac{\tau_{t}^{h}}{\tau^{h * *}}\right)=\left(\frac{y_{t}}{y^{* *}}\right)^{\delta_{0}}
$$

This allows to assess the contribution of short-run tax adjustments to output stabilization, where taxes immediately impact on RT consumers' disposable income. Due to LAMP, temporary redistributive policies may have powerful stabilisation effects on RT consumption but no effect on Ricardian households. To investigate this issue we also assume that transfers to RT consumers evolve according to the following rule:

$$
\left(\frac{t r_{y, t}}{t r_{y}}\right)=\left(\frac{y_{t}}{y^{* *}}\right)^{-\delta_{1}}
$$

where $\operatorname{tr}_{y}=\left(T R^{*} / y^{*}\right)=\left(T R^{* *} / y^{* *}\right)$ is the constant public transfer-to-GDP target ratio and $t r_{y, t} \equiv\left(T R_{t} / y^{* *}\right)$ defines time $t$ levels of public transfers in terms of post-consolidation steady-state output. We also assume that steady state transfers are payed only to constrained households, as in Coenen et al., 2008).

\footnotetext{
${ }^{5}$ See also Van den Noord (2000), Westaway (2003) and Andres and Domenech (2006).
} 


\subsection{Monetary Policy}

The monetary authority sets its policy instrument $R_{t}$ according to a standard Taylor rule:

$$
\left(\frac{R_{t}}{R}\right)=\left(\frac{\pi_{t}}{\pi}\right)^{\phi_{\pi}}\left(\frac{y_{t}}{y^{* *}}\right)^{\phi_{y}}
$$

where $\pi_{t}, \pi, R$ and $y_{t} / y^{* *}$ respectively denote the inflation rate, the inflation target, the interest rate target and the output gap defined with reference to the post-consolidation steady state.

\subsection{Calibration}

The baseline calibration of structural parameters follows SW who estimate a DSGE model for the euro area. Table 1 summarizes parameters values and their description.

(Table 1 here)

As for fiscal sector, the parameter governing the debt stabilization $\phi_{g}$ in the government spending rule is set equal to 1 , in line with the debt reduction experiment carried out by CMS. As in Colciago et al. (2008), fiscal responses to output - $\delta_{0}$ in (4) and $\delta_{1}$ in (5) - are calibrated at 0.5 . This value is also consistent with the empirical evidence in Van den Noord (2000) and adopted in studies on fiscal stabilization (e.g. Westaway, 2003). Moreover, to guarantee the inertial behavior of taxes according to (3) we set $\phi^{\tau}=0.01$. Furthemore, we draw from the estimates reported in Mendoza, Razin and Tesar (1994) to assign the 
value to the average effective capital-labor tax rate $\operatorname{ratio}^{6}$, i.e. $\left(\frac{\tau^{k * *}}{\tau^{h * *}}\right)=0.92^{7}$. Finally, the public spending and transfer steady state ratios are both fixed at 0.18, consistently with the national accounts data for Euro Area countries. ${ }^{8}$

As for monetary policy, the parameter governing inflation stabilization $\phi_{\pi}$ is calibrated at 1.5 , in line with a conservative parametrisation in the literature and the parameter governing output stabilization $\phi_{y}$ is set at 0.5 , according to the classical Taylor rule specification.

The parameter denoting the weight of public spending in the utility function $\xi$ is set at a level such that the calibrated public consumption to GDP ratio is indeed optimal according to the social planner choice and temporary expenditure reductions lower welfare.

The fraction of population following the rule of thumb in the Euro Area is estimated by the empirical evidence ${ }^{9}$ in a range between 0.25 and 0.50 . Following Campbell and Mankiw (1989), we fix the fraction of liquidity constrained consumers at 0.50. As a matter of fact, raising the share of RT consumer "stacks the cards" against the possibility that the tax reductions necessary to stabilize consumption do not substantially slow down the pace of debt reduction.

\footnotetext{
${ }^{6}$ In particular, while the labor tax rate is calibrated such that the fiscal authority's budget is balanced at the debt-to-GDP target, the capital tax rate is anchored to the capital-labor tax rate ratio.

${ }^{7}$ Results hold for different values of capital-labor tax rate ratios found in the literature, (Coenen et al., 2008; SGU, 2005)

${ }^{8}$ Our results would not change if we used instead the corresponding ratios that charaterise the US economy.

${ }^{9}$ See, for instance, Coenen and Straub (2005), Forni et al. (2009). Albonico Paccagnini and Tirelli $(2014,2016)$ estimate a $50 \%$ share for both the EMU and the US..
} 


\section{Results}

\subsection{The Long-Run Effects of Fiscal Consolidation}

In Table 2 we report the steady state adjustment of some key variables in consequence of the fiscal consolidation.

(Table 2 here)

In particular, $k^{* *} / h^{* *}$ is the capital labor ratio, $w$ denotes the real wage,

$c_{p c}^{o * *}$ and $c_{p c}^{r t * *}$ respectively define the per-capita consumption levels of the two household types.

The fiscal consolidation improves the budgetary position of the government. These resources are used to lower labor and capital income taxes. This, in turn, causes an output expansion, due to an increase in both capital and labor supply. RT consumption unambiguously increases. Just like RT consumers, Ricardian households benefit from the labor tax reduction. In addition they entirely appropriate the capital income tax reduction. However, they loose public debt service payments. As a result, the steady state variation in their consumption is negative.

\subsection{Transition Dynamics}

The next step in our analysis is a discussion of the short-run effects under different fiscal and monetary rules. We consider alternative scenarios.

1. No short-run fiscal stabilization and pure inflation targeting. In this case we are able to identify the role of "pure" announcements of future tax 
reductions. The tax rule follows (3), transfers are held constant and we set $\phi_{y}=0$ in $(6)$.

2. Short run fiscal stabilization is based on (4), constant transfers and pure inflation targeting.

3. Taxes follow (3), monetary policy is a pure inflation targeter and transfers to RT consumers are activated as stabilizers according to (5).

4. The Taylor rule reacts to the output gap, i.e. $\phi_{y}=0.5$. We consider the contribution of output gap targeting under the alternative tax rules described in (4) and in (5), scenarios $\mathbf{4 a}$ and $\mathbf{4} \mathbf{b}$, respectively.

In the following we report transition paths for the relevant variables under scenarios 1-4. Each panel shows the transition dynamics starting from the initial steady state in which the value of the debt-to-GDP ratio is equal to $70 \%{ }^{10}$.

\subsection{Scenario 1. No fiscal stabilizers and pure inflation targeting}

Figure 2 reports dynamics under scenario 1. Achieving the desired fall in the debt-to-GDP ratio takes about 37 quarters. Consider first what happens when all agents are Ricardian (blue line). After the government consumption reduction of about 2.5 percentage points, the output contraction is unavoidable. This is in turn associated to a lower real wage. As a consequence, marginal

\footnotetext{
${ }^{10}$ All dynamic effects are reported as percentage deviations from the initial steady state, with the exception of fiscal ratios which are reported in absolute values.
} 
costs fall, bringing down inflation and interest rates. Note that without RT agents the output reduction is associated with a boom in consumption, which initially overshoots its new long-run level. In line with previous contributions in thies field (see, for instance, Linnemann and Schabert, 2003), expenditure-based fiscal consolidations produce a gain without pain because private consumption rises and the labor supply falls.

Under LAMP (red line) the initial output fall is larger due to the fall in RT consumption. Note that in this case the fiscal consolidation causes a temporary but strong increase in consumption inequality. In fact while Ricardian households raise their consumption, RT households do just the opposite in consequence of the fall in their current income. ${ }^{11}$

(Figure 2 here)

\subsection{Scenario 2. Tax stabilizers and pure inflation target- ing}

Relatively to Scenario 1, taxes undershoot their long-run fall in response to the short-run output reduction (Figure 3). This boosts RT households' disposable income and consumption. The gain without pain result is restored. Aggregate demand increases and the recession softens. This result is obtained at the cost

\footnotetext{
${ }^{11}$ We implemented some robustness checks. In separate exercies, we increased the habit parameter value from 0.60 (baseline) to 0.80 (Bouakez, et al., 2005, report a 0.98 value, see Havránek et al., 2015, for a survey), and we reduced the wage stickyness parameter value from 0.75 (baseline) to 0.60 (as in Basu and House, 2016). Results unambiguously suggest that the short run contractionary effect of a consolidation might be stronger than in our baseline scenario.
} 
of slowing down the speed of debt reduction, which is now achieved in about 44 quarters.

(Figure 3 here)

\subsection{Scenario 3. Stabilization through redistribution}

Stabilization through redistribution allows to both reduce debt and boost consumption. In Figure 4, stabilization by means of transfers policy (red line) only operates through the demand-side effect stemming from RT consumption, whereas use of taxes (blue line) produces favourable supply side effects that raise output and labor income, thus increasing RT consumption. In addition, the tax fall lowers marginal costs and induces a larger interest rate reduction. This, in turn, stimulates Ricardian households consumption and strengthens the recovery of output. As a result we obtain that a pure demand-side fiscal policy is less effective in stimulating output convergence and has a weaker effect on RT consumption. The other side of the coin is that stabilization through transfers entails a much faster speed of debt reduction, which is completed in about 38 quarters, and a quicker convergence of public consumption to the new steady state level.

(Figure 4 here)

\subsection{Scenario 4. Monetary policy reacts to the output gap}

Figure $5 \mathrm{a}$ and $5 \mathrm{~b}$ compare the effects of a countercyclical monetary policy complementing fiscal policy under rules (4) and (5), respectively. Relative to scenar- 
ios 2 and 3, output gap targeting causes a larger interest rate fall. This, in turn, causes a much stronger increase in Ricardian consumption and has beneficial effects on labor incomes and RT consumption. As a result the monetary policy achieves better inflation stabilization and faster convergence of the debt ratio to the new target $b_{y}^{* *}$.

(Figure 5a here)

(Figure 5b here)

\section{Welfare analysis}

This section reports in Table 3 the welfare effects of fiscal consolidation.

(Table 3)

We use the consumption equivalent measure (CEM) to compute the welfarebased ratio ${ }^{12}$, as in Ascari and Ropele (2012). The CEM defines the fraction of steady state consumption that households have to give up to permanently reduce public debt. The welfare ratio is thus the ratio between CEM and the consolidation size. Since CEM is a welfare cost, fiscal consolidation is welfare improving if the welfare ratio is negative.

In the post-consolidation steady state, RT consumers unambiguously benefit from the fiscal consolidation. Indeed, they gain about an extra $8 \%$ of consumption. Ricardian consumers benefit from a far smaller welfare increase. Given

\footnotetext{
${ }^{12}$ Appendix $\mathrm{C}$ shows the derivation of the consumption equivalent measure and of the welfare-based ratio.
} 
that in the new steady state these households consume less and work more, this result is entirely determined by the beneficial effects of increased public consumption $G$, as documented in Table 2 .

Let's now consider the distributional effects during the transition, according to the different policy scenarios. RT households unambiguously suffer, irrespective of the policy scenario that is being implemented. The reason why this happens is that even when fiscal stabilizers are used to support their consumption, their welfare during the transition is reduced by the public consumption contraction. Their preferred policy scenario is $4 \mathrm{a}$, which entails an output gap targeting using both interest rate and tax rules. In spite of the favorable income redistribution obtained under transfer policies, scenarios 3 and $4 \mathrm{~b}$ are not particularly helpful for RT households. The reason lies in the quicker consolidation process, associated to a less persistent fiscal support to their consumption relative to what happens when tax stabilizers are implemented.

Ricardian households preferred scenario is 2 that, relative to cases 1 and 3 , is characterized by a prolonged persistence of their consumption above its post-consolidation steady state level. Differently from what happens to RT consumers, the inclusion of an output gap feedback in the Taylor rule brings no benefit to these households. 


\section{Extensions: The Zero Lower Bound Issue}

In this section we consider the implications of implementing consolidation plans associated to higher initial levels of public debt $\left(b_{y}^{*}=100 \%, b_{y}^{*}=120 \%\right)$. Under these assumptions, all previous results qualitatively hold, but the amplitude of short and long run adjustments is obviously larger. Our calculations show that under LAMP, but not under the representative agent assumption, the initial output slump may cause an inflation fall so strong that the interest rate gets very close to the zero lower bound (ZLB henceforth $)^{13}$.

(Figures 6a and 6b here)

Note that attempts to stabilize the economy by reducing taxes (scenario 2), while unambiguously effective and desirable for their effects on welfare, typically generate a stronger reduction in the nominal interest rate. Thus we observe an apparent tradeoff between the beneficial welfare effects of tax stabilization policies and the fragility of the macroeconomy, defined as the increased probability of hitting the ZLB. This result is better understood taking into account that the tax rule raises output but lowers marginal costs and therefore reduces inflation. This is the key factor that drives the nominal interest closer to the ZLB under scenario 2. By contrast under scenario 3 (public transfers stabilize the economy) the fiscal policy has no direct effect on marginal costs and the inflation rate fall is substantially dampened. We do not plot results for large consolidations under scenarios $4 \mathrm{a}$ and $4 \mathrm{~b}$ because the feedback on the output gap brings the interest

\footnotetext{
${ }^{13}$ We assume that steady state inflation is $2 \%$.
} 
rate to the ZLB for the fiscal feedbacks calibrations adopted in the previous section.

\section{Conclusions}

This paper shows that an appropriate mix of fiscal and monetary policies can substantially ease the strain typically associated to fiscal consolidations. The public expenditure reduction should be supported either by a temporary public transfers increase or by a tax rates fall that undershoots their new post consolidation values. Such policies have a strong stabilizing effect on the disposable income of RT consumers. This, in turn, stimulates demand and supports growth. As a result, the pace of debt reduction is substantially preserved because the revenues loss from lower tax rates (larger transfers) is largely compensated for by an increase in the tax base. The result is even strengthened when the monetary authority targets both inflation and output gap. In this case the stronger interest rate fall is beneficial because it exploits the complementarity between the consumption of Ricardian households and the disposable income of RT consumers.

Our analysis shows that choosing tax reductions generates larger welfare gains, but transfers reduce the risk of hitting the ZLB because they have a relatively stronger impact on inflation. This latter result has potentially important implications in the current EMU predicament, where perypheral countries are striving to reduce debt-to-GDP ratios but the ECB interest rate policy is already 
constrained by the ZLB. In fact our results suggest that expenditure reductions should be complemented by fiscal stimuli that limit further downward pressure on inflation.

Our results bear immediate implications for fiscal consolidation plans in the Eurozone. To avoid activation of the SGP 'corrective arm', countries whose debt-to-GDP ratio exceeds $60 \%$ are requested to implement strict debt reduction plans, with the notable potential exception of the flexibility clauses that go under three headings: exceptional circumstances, structural reforms and public investment (see Micossi and Peirce, 2014, for a discussion). Budgetary flexibility is therefore justified to "compensate the loosers" when reforms are introduced and to catch up with the loss of public infrastructure. In both cases an implicit trade-off is accepted between debt consolidation and other efficiency-enhancing policy actions. By contrast, social issues associated to fiscal consolidations are completely neglected. The Communication on strengthening the social dimension of the Economic and Monetary Union (European Commission 2013) enphasized the importance of reconsidering the social implications of policy actions and reforms and has identified a new scoreboard of social indicators. Few would question the claim that such indicators point at a dramatic deterioration of the social situation in all EMU countries involved in large debt consolidation plans. Our results provide a new perspective on how to avoid fiscal consolidations turning into a social catastrophe. 


\section{References}

[1] Agnello L., xSousa, R.M., 2014. "How Does Fiscal Consolidation Impact on Income Inequality?," Review of Income and Wealth, International Association for Research in Income and Wealth, vol. 60(4), pages 702-726, December.

[2] Alesina Alberto \& Silvia Ardagna, 2010. "Large Changes in Fiscal Policy: Taxes versus Spending," NBER Chapters, in: Tax Policy and the Economy, Volume 24, pages 35-68 National Bureau of Economic Research, Inc.

[3] Alesina Alberto \& Silvia Ardagna, 2013. "The Design of Fiscal Adjustments," NBER Chapters, in: Tax Policy and the Economy, Volume 27 National Bureau of Economic Research, Inc.

[4] Alesina, Alberto F \& Favero, Carlo A. \& Giavazzi, Francesco, 2012. "The output effect of fiscal consolidations," CEPR Discussion Papers 9105, C.E.P.R. Discussion Papers.

[5] Albonico A, Paccagnini A, Tirelli P, 2014. Estimating a DSGE model with Limited Asset Market Participation for the Euro Area, Working Papers 286, University of Milano-Bicocca, Department of Economics, Journal of Economic Dynamics and Control forthcoming

[6] Albonico A, Paccagnini A, Tirelli P, 2016. In search of the Euro Area Fiscal Stance, Working Papers 324, Journal of Empirical Finance, available online 5 July 
[7] Almeida Vanda \& Gabriela Castro \& Ricardo Mourinho Félix \& José R. Maria, 2013. "Fiscal Consolidation in a Small Euro-Area Economy," International Journal of Central Banking, International Journal of Central Banking, vol. 9(4), pages 1-38, December.

[8] Anderson, Emily \& Inoue, Atsushi \& Rossi, Barbara, 2013. "Heterogeneous Consumers and Fiscal Policy Shocks," CEPR Discussion Papers 9631, C.E.P.R. Discussion Papers.

[9] Andres, Javier \& Domenech, Rafael, 2006. "Automatic stabilizers, fiscal rules and macroeconomic stability," European Economic Review, Elsevier, vol. 50(6), pages 1487-1506, August.

[10] Ascari, Guido \& Ropele, Tiziano, 2012. "Disinflation in a DSGE perspective: Sacrifice ratio or welfare gain ratio?," Journal of Economic Dynamics and Control, Elsevier, vol. 36(2), pages 169-182.

[11] Ball Laurence M. \& Davide Furceri \& Daniel Leigh \& Prakash Loungani, 2013. "The Distributional Effects of Fiscal Consolidation," IMF Working Papers 13/151, International Monetary Fund.

[12] Basu, S. and House, C.L., 2016. Challenges for New Keynesian Models with Sticky Wages. Prepared for the Handbook of Macroeconomics, ed. by JB Taylor and H. Uhlig, Elsevier, 2.

[13] Bouakez, H., Cardia, E. , and Ruge-Murcia, F. J. (2005): Habit Formation and the Persistence of Monetary Shocks, Journal of Monetary Economics, 52. 
[14] Bilbiie, Florin O., 2008. "Limited asset markets participation, monetary policy and (inverted) aggregate demand logic," Journal of Economic Theory, Elsevier, vol. 140(1), pages 162-196, May.

[15] Calvo, Guillermo A., 1983. "Staggered prices in a utility-maximizing framework," Journal of Monetary Economics, Elsevier, vol. 12(3), pages 383-398, September.

[16] Campbell John Y. \& N. Gregory Mankiw, 1989. "Consumption, Income and Interest Rates: Reinterpreting the Time Series Evidence," NBER Chapters, in: NBER Macroeconomics Annual 1989, Volume 4, pages 185-246 National Bureau of Economic Research, Inc.

[17] Chamley, Christophe, 1986. "Optimal Taxation of Capital Income in General Equilibrium with Infinite Lives," Econometrica, Econometric Society, vol. 54(3), pages 607-22, May.

[18] Christiano Lawrence J. \& Martin Eichenbaum \& Charles L. Evans, 2005. "Nominal Rigidities and the Dynamic Effects of a Shock to Monetary Policy," Journal of Political Economy, University of Chicago Press, vol. 113(1), pages $1-45$, February.

[19] Coenen, Günter \& Mohr, Matthias \& Straub, Roland, 2008. "Fiscal consolidation in the euro area: Long-run benefits and short-run costs," Economic Modelling, Elsevier, vol. 25(5), pages 912-932, September.

[20] Coenen Günter \& Roland Straub, 2005. "Does Government Spending Crowd in Private Consumption? Theory and Empirical Evidence for the 
Euro Area," International Finance, Wiley Blackwell, vol. 8(3), pages 435470, December.

[21] Cogan, John F. \& Taylor, John B. \& Wieland, Volker \& Wolters, Maik H., 2013. "Fiscal consolidation strategy," Journal of Economic Dynamics and Control, Elsevier, vol. 37(2), pages 404-421.

[22] Colciago Andrea, 2011. "Rule-of-Thumb Consumers Meet Sticky Wages," Journal of Money, Credit and Banking, Blackwell Publishing, vol. 43, pages 325-353, 03.

[23] Colciago Andrea \& Tiziano Ropele \& V. Anton Muscatelli \& Patrizio Tirelli, 2008. "The Role of Fiscal Policy in a Monetary Union: are National Automatic Stabilizers Effective?," Review of International Economics, Wiley Blackwell, vol. 16(3), pages 591-610, 08.

[24] Corsetti, G. 2012. "Austerity: Too much of a Good Thing. A VoxEU.org eCollection of views by leading economists". London: Centre for Economic Policy Research (CEPR).

[25] Cowell Frank \& Eleni Karagiannaki \& Abigail McKnight, 2012. "Mapping and measuring the distribution of household wealth: a cross-country analysis," LSE Research Online Documents on Economics 51288, London School of Economics and Political Science, LSE Library.

[26] Darvas Zsolt \& Olga Tschekassin, 2015. "Poor and under pressure: the social impact of Europe's fiscal consolidation," Policy Contributions 877, Bruegel. 
[27] European Commission, 2013. "Strengthening the social dimension of the Economic and Monetary Union: frequently asked questions." http://europa.eu/rapid/press-release_MEMO-13-837_en.htm

[28] Forni, Lorenzo \& Monteforte, Libero \& Sessa, Luca, 2009. "The general equilibrium effects of fiscal policy: Estimates for the Euro area," Journal of Public Economics, Elsevier, vol. 93(3-4), pages 559-585, April.

[29] Furlanetto Francesco \& Martin Seneca, 2012. "Rule-of-Thumb Consumers, Productivity, and Hours," Scandinavian Journal of Economics, Wiley Blackwell, vol. 114(2), pages 658-679, 06.

[30] Galí, Jordi \& Lopez-Salido, Jose David \& Vallés Liberal, Javier, 2004. "Rule-of-Thumb Consumers and the Design of Interest Rate Rules," CEPR Discussion Papers 4347, C.E.P.R. Discussion Papers.

[31] Galí Jordi \& J. David López-Salido \& Javier Vallés, 2007. "Understanding the Effects of Government Spending on Consumption," Journal of the European Economic Association, MIT Press, vol. 5(1), pages 227-270, 03.

[32] Garcia-Milà Teresa \& Albert Marcet \& Eva Ventura, 2010. "Supply Side Interventions and Redistribution," Economic Journal, Royal Economic Society, vol. 120(543), pages 105-130, 03.

[33] Greulich Katharina \& Albert Marcet, 2008. "Pareto-Improving Optimal Capital and Labor Taxes," Working Papers 337, Barcelona Graduate School of Economics. 
[34] Guo, Jang-Ting \& Lansing, Kevin J., 1999. "Optimal taxation of capital income with imperfectly competitive product markets," Journal of Economic Dynamics and Control, Elsevier, vol. 23(7), pages 967-995, June.

[35] Havránek, T., Rusnák, M., \& Sokolova, A. (2015). Habit Formation in Consumption: A Meta-Analysis. WP: Czech National Bank. http://metaanalysis. cz/habits.

[36] Heathcote Jonathan \& Fabrizio Perri \& Giovanni L. Violante, 2010. "Unequal We Stand: An Empirical Analysis of Economic Inequality in the United States: 1967-2006," Review of Economic Dynamics, Elsevier for the Society for Economic Dynamics, vol. 13(1), pages 15-51, January.

[37] Iacoviello, Matteo \& Pavan, Marina, 2013. "Housing and debt over the life cycle and over the business cycle," Journal of Monetary Economics, Elsevier, vol. 60(2), pages 221-238.

[38] IMF, 2013. "Fiscal Monitor. Taxing Times." World Economic and Financial Surveys 0258-7440

[39] Judd, Kenneth L., 1999. "Optimal taxation and spending in general competitive growth models," Journal of Public Economics, Elsevier, vol. 71(1), pages 1-26, January.

[40] Kaplanoglou, Georgia \& Rapanos, Vassilis T., 2015. "Why do people evade taxes? New experimental evidence from Greece," Journal of Behavioral and Experimental Economics (formerly The Journal of Socio-Economics), Elsevier, vol. 56(C), pages 21-32. 
[41] Krueger, Alan B. \& Mueller, Andreas, 2010. "Job search and unemployment insurance: New evidence from time use data," Journal of Public Economics, Elsevier, vol. 94(3-4), pages 298-307, April.

[42] Lansing Kevin J. \& Agnieszka Markiewicz, 2013. "Top Incomes, Rising Inequality, and Welfare," CDMA Working Paper Series 201304, Centre for Dynamic Macroeconomic Analysis.

[43] Linnemann, Ludger \& Schabert, Andreas, 2003. " Fiscal Policy in the New Neoclassical Synthesis," Journal of Money, Credit and Banking, Blackwell Publishing, vol. 35(6), pages 911-29, December.

[44] Maestri Virginia \& Roventini, A. (Andrea), 2012. "GINI DP 30: Stylized Facts on Business Cycles and Inequality," GINI Discussion Papers 30, AIAS, Amsterdam Institute for Advanced Labour Studies.

[45] Mendoza, Enrique G. \& Razin, Assaf \& Tesar, Linda L., 1994. "Effective tax rates in macroeconomics: Cross-country estimates of tax rates on factor incomes and consumption," Journal of Monetary Economics, Elsevier, vol. 34(3), pages 297-323, December.

[46] Micossi, S, and Peirce, F., 2014. "Flexibility clauses in the Stability and Growth Pact: No need for revision". CEPS policy Brief No. 319.

[47] Molnar Margit, 2012. "Fiscal Consolidation: Part 5. What Factors Determine the Success of Consolidation Efforts?," OECD Economics Department Working Papers 936, OECD Publishing. 
[48] Motta Giorgio \& Patrizio Tirelli, 2012. "Optimal Simple Monetary and Fiscal Rules under Limited Asset Market Participation," Journal of Money, Credit and Banking, Blackwell Publishing, vol. 44(7), pages 1351-1374, October.

[49] Motta Giorgio \& Patrizio Tirelli, 2013. "Limited Asset Market Participation, Income Inequality and Macroeconomic Volatility," Working Papers 261, University of Milano-Bicocca, Department of Economics, revised Dec 2013.

[50] Mulas-Granados, C. (2005), "Fiscal adjustments and the short-term tradeoff between economic growth and equality," Revista de Economia Pública, 172(1), 61-92.

[51] Nickel, Christiane \& Rother, Philipp \& Zimmermann, Lilli, 2010. "Major public debt reductions: Lessons from the past, lessons for the future," Working Paper Series 1241, European Central Bank.

[52] OECD 2012. "Fiscal Consolidation: How Much is Needed to Reduce Debt to a Prudent Level?", OECD Economics Department Policy Notes, No. 11, April.

[53] OECD 2013. "How much scope for growth and equity-friendly fiscal consolidation?", OECD Economics Department Policy Notes, No. 20 July 2013.

[54] Perotti Roberto, 2012. "The "Austerity Myth": Gain without Pain?," NBER Chapters, in: Fiscal Policy after the Financial Crisis, pages 307354 National Bureau of Economic Research, Inc. 
[55] Rawdanowicz Lukasz \& Eckhard Wurzel \& Ane Kathrine Christensen, 2013. "The Equity Implications of Fiscal Consolidation," OECD Economics Department Working Papers 1013, OECD Publishing.

[56] Schmitt-Grohé Stephanie \& Martin Uribe, 2005. "Optimal Fiscal and Monetary Policy in a Medium-Scale Macroeconomic Model: Expanded Version," NBER Working Papers 11417, National Bureau of Economic Research, Inc.

[57] Schmitt-Grohé, Stephanie \& Uribe, Martin, 2007. "Optimal simple and implementable monetary and fiscal rules," Journal of Monetary Economics, Elsevier, vol. 54(6), pages 1702-1725, September.

[58] Smets Frank \& Raf Wouters, 2003. "An Estimated Dynamic Stochastic General Equilibrium Model of the Euro Area," Journal of the European Economic Association, MIT Press, vol. 1(5), pages 1123-1175, 09.

[59] van den Noord Paul, 2000. "The Size and Role of Automatic Fiscal Stabilizers in the 1990s and Beyond," OECD Economics Department Working Papers 230, OECD Publishing.

[60] Westaway Peter, F., 2003. "Modelling Shocks and Adjustment Mechanism in EMU". EMU Studies London: HM Treasury.

[61] Woo Jaejoon \& Elva Bova \& Tidiane Kinda \& Yuanyan Sophia Zhang, 2013. "Distributional Consequences of Fiscal Consolidation and the Role of Fiscal Policy: What Do the Data Say?," IMF Working Papers 13/195, International Monetary Fund. 


\section{Appendix A: Figures and Tables.}

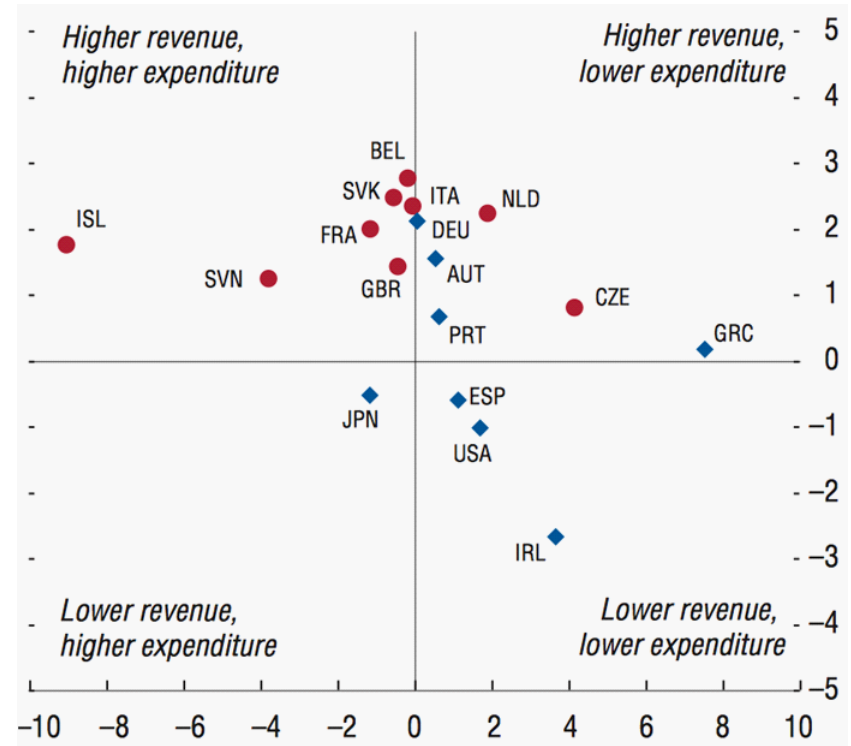

Fig.1-Change in planned measures 2009-2013. (Source: IMF, 2013). Orizontal axis: expenditure cuts relative to plans (\% of potential GDP). Vertical axis:

revenue increases relative to plans ( $\%$ of potential GDP)
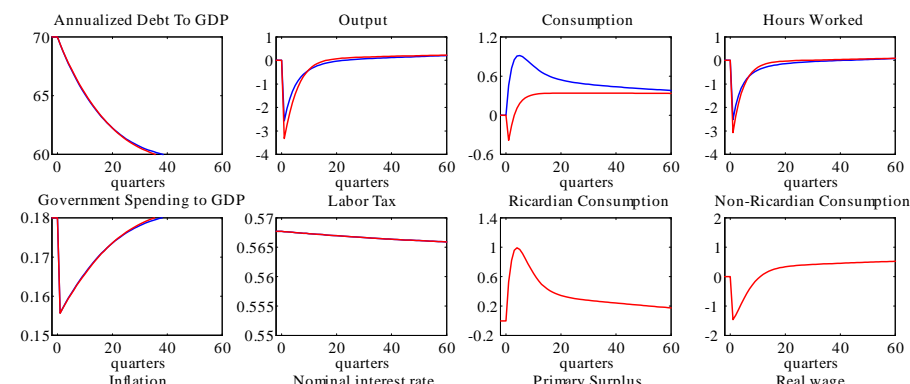

Non-Ricardian Consumption
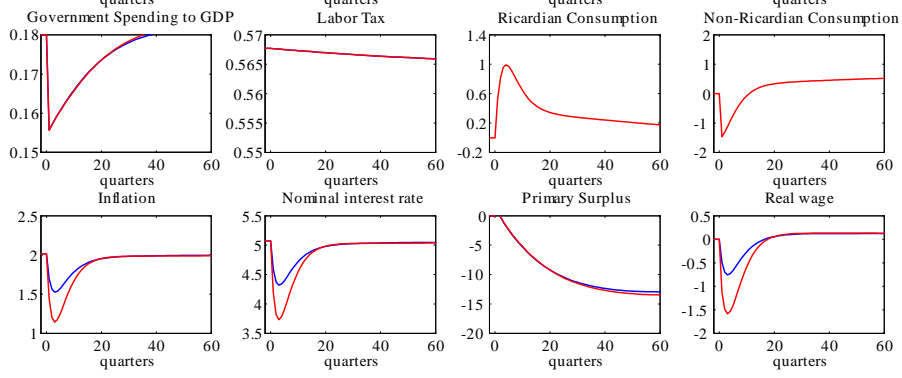

- Scenario 1 (No fiscal stabilizers, pure inflation targeting, RT=0)

- Scenario 1 (No fiscal stabilizers, pure inflation targeting, $\mathrm{RT}=0.5$ )

Fig.2-Short run effects of fiscal consolidation 

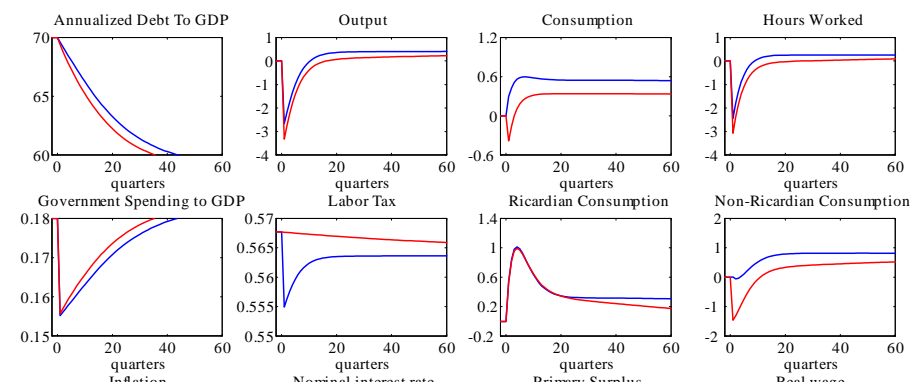

quarters
Non-Ricardian Consunption
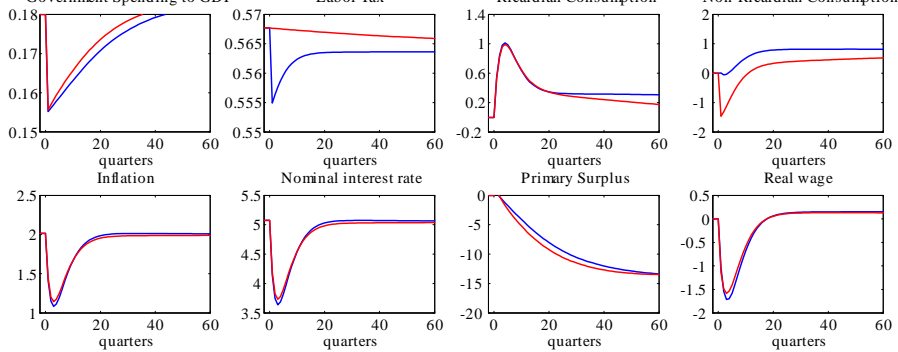

- Scenario 1 (No fiscal stabilizers and pure inflation targeting)

Fig.3 -Tax stabilizers vs tax reduction "announcement"
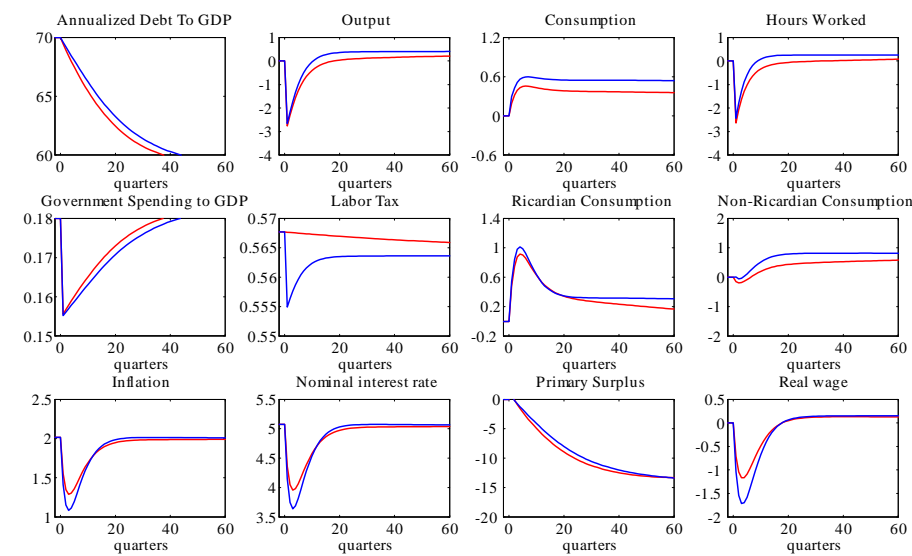

Non-Ricardian Consumptio
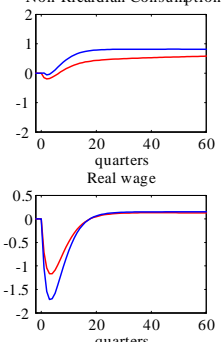

-Scenario 3 (Transfer stabilizers and pure inflation targeting)

- Scenario 2 (Tax stabilizers and pure inflation targeting)

Fig.4 -Transfer stabilizers vs tax stabilizers 

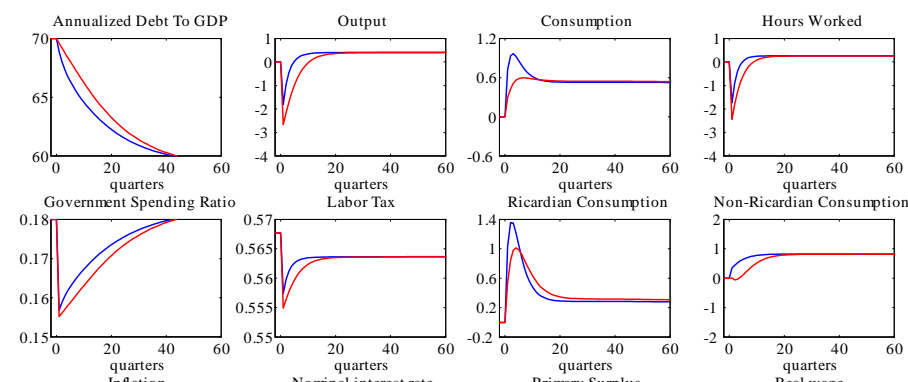

quarters
Non-Ricardian Consumption
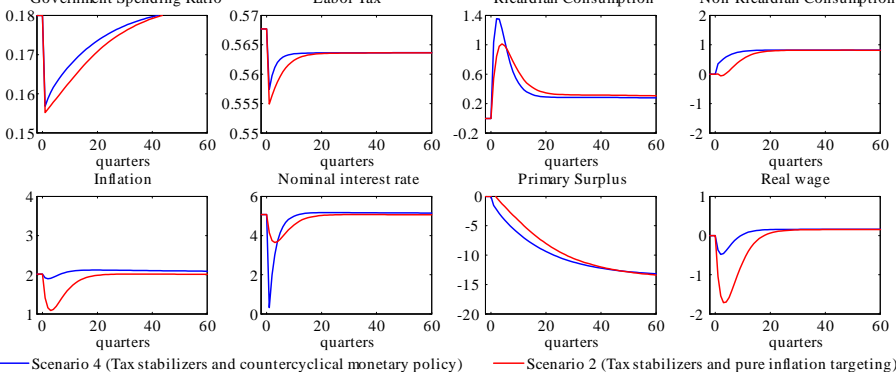

— Scenario 2 (Tax stabilizers and pure iuarters

Fig.5a - Countercyclical monetary policy and scenario 2
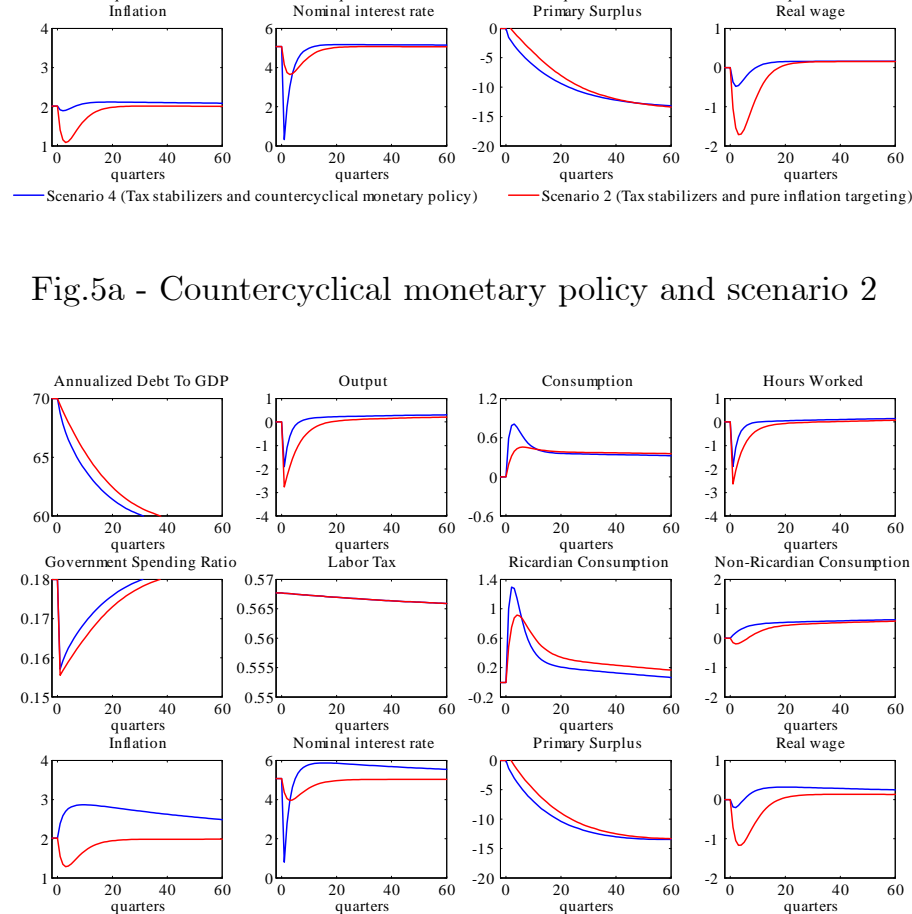

Non-Ricardian Consumption

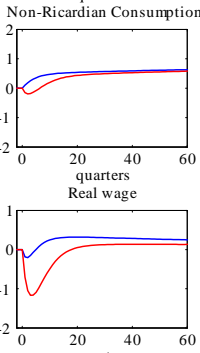

- Scenario 4 (Transfer stabilizers and countercyclical monetary policy)

— Scenario 3 (Transfer stabilizers and pure inflation targeting)

Fig.5b - Countercyclical monetary policy and Scenario 3 


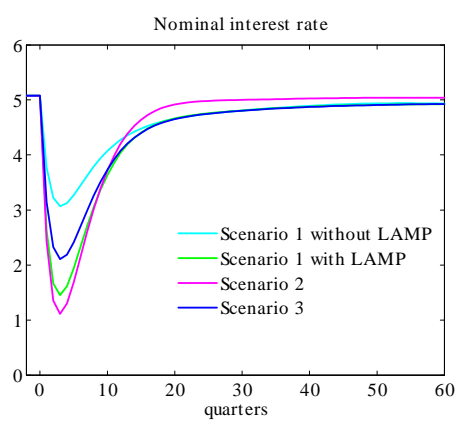

Fig. 6a - Nominal interest rate path under fiscal consolidation from $100 \%$

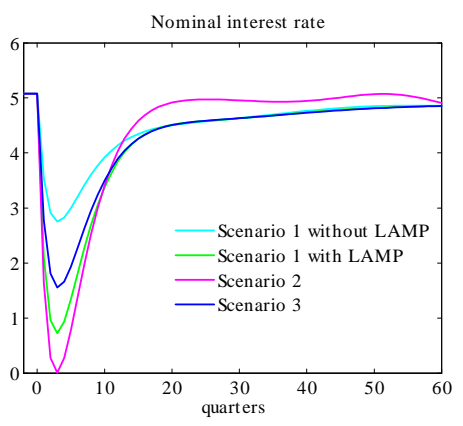

Fig. 6b - Nominal interest rate path under fiscal consolidation

from $120 \%$ 


$\begin{array}{lll}\begin{array}{l}\text { Table 1a: Parameter } \text { Values } \\ \text { Parameter }\end{array} & \text { Value } & \text { Description } \\ \text { Households } & & \\ \beta & 1.03^{(-1 / 4)} & \text { Subjective discount factor } \\ b & 0.60 & \text { Degree of habit persistence } \\ \phi & 2 & \text { Inverse of intertemporal substitution of labor } \\ \phi_{1} & 1.1196 & \text { Disutility of work } \\ \xi & 0.27 & \text { Weight of government expenditures } \\ \eta_{w} & 6 & \text { Wage elasticity of demand for a specific labor variety } \\ \Omega & 0.50 & \text { Share of Rule of Thumb consumers }{ }^{14} \\ \alpha_{w} & 0.75 & \text { Calvo wage } \\ \chi_{w} & 0.75 & \text { Wage indexation }\end{array}$

${ }^{14}$ Campbell and Mankiw (1989), Mankiw (2000) 
Table 1b: Parameter Values

$\begin{array}{lll}\text { Parameter } & \text { Value } & \text { Description } \\ \text { Firms } & & \\ \vartheta & 0.30 & \text { Share of capital in value added } \\ \delta & 0.025 & \text { Depreciation rate of capital } \\ \eta & 6 & \text { Price elasticity of demand for a specific good variety } \\ \alpha & 0.9 & \text { Calvo price } \\ \chi & 0.50 & \text { Price indexation } \\ \nu & 0.15 & \text { Cash in advance parameter }\end{array}$




\begin{tabular}{|c|c|c|}
\hline Parameter & Value & Description \\
\hline \multicolumn{3}{|l|}{ Fiscal Sector } \\
\hline$b y^{* *}$ & $60 \%$ & Debt-to-output ratio target (annual) \\
\hline$g^{*}=g^{* *}$ & $18 \%$ & Government expenditure ratio \\
\hline$t r^{*}=t r^{* *}$ & $18 \%$ & Transfers ratio \\
\hline$\tau_{k}^{*}$ & $52.23 \%$ & Capital tax rate (old target) \\
\hline$\tau_{k}^{* *}$ & $51.86 \%$ & Capital tax rate (new target) \\
\hline$\tau_{h}^{*}$ & $56.77 \%$ & Labor tax rate (old target) \\
\hline$\tau_{h}^{* *}$ & $56.37 \%$ & Labor tax rate (new target) \\
\hline$\left(\frac{\tau_{k}^{*}}{\tau_{h}^{*}}\right)=\left(\frac{\tau_{k}^{* *}}{\tau_{h}^{* *}}\right)$ & $92 \%$ & Tax rate ratios \\
\hline$\phi_{g}$ & 1 & Debt stabilization \\
\hline$\phi_{\tau}$ & 0.01 & Tax rate dynamics \\
\hline$\delta_{0}$ & 0.5 & Transfer response to output \\
\hline$\delta_{1}$ & 0.5 & Tax response to output \\
\hline \multicolumn{3}{|c|}{ Monetary Authority } \\
\hline$\phi_{\pi}$ & 1.5 & Inflation stabilization \\
\hline$\phi_{y}$ & 0.5 & Output stabilization \\
\hline
\end{tabular}


Table 2 - Steady state percentage variations after consolidation

\begin{tabular}{ll}
\hline$\Delta \tau^{h * *}=-0.70$ & $\Delta\left(\frac{k^{* *}}{h^{* *}}\right)=0.42$ \\
$\Delta \tau^{k * *}=-0.70$ & $\Delta h^{* *}=0.31$ \\
$\Delta y^{* *}=\Delta G^{* *}=0.43$ & $\Delta w^{* *}=0.13$ \\
$\Delta c_{p c}^{o * *}=-0.02$ & $\Delta c_{p c}^{r t * *}=0.82$ \\
\hline
\end{tabular}

Table 3 - Welfare Effects

\begin{tabular}{llll}
\hline \hline & & & \\
Scenarios & Welf. measure & Ricardian h. & Non-Ricardian h. \\
\hline & $W R_{\text {long_run }}^{J}$ & -0.0250 & -8.36 \\
1 & $W R_{\text {short_run }}^{J}$ & -0.2950 & 4.42 \\
2 & $W R_{\text {short_run }}^{J}$ & -1.5750 & 1.73 \\
3 & $W R_{\text {short_run }}^{J}$ & 0.2050 & 3.93 \\
$4 \mathrm{a}$ & $W R_{\text {short_run }}^{J}$ & -1.5250 & 1.26 \\
$4 \mathrm{~b}$ & $W R_{\text {short_run }}^{J}$ & 0.1650 & 2.58 \\
\hline
\end{tabular}

All the values are expressed in percentage terms 


\section{Appendix B: The Model}

\subsection{Households}

There is a continuum of households indexed by $i, i \in[0,1] . \quad R T(r t)$ and Ricardian $(o)$ agents are respectively defined over the intervals $[0, \Omega]$ and $[\Omega, 1]$. All households share the same utility function.

$$
U_{t}^{i}=E_{0} \sum_{t=0}^{\infty} \beta^{t}\left\{\ln \left(c_{t}^{i}-b c_{t-1}^{i}\right)-\frac{\phi_{1}}{(1+\phi)}\left(h_{t}^{i}\right)^{(1+\phi)}+\xi \ln G_{t}\right\}
$$

\subsection{Consumption bundles}

The consumption good is assumed to be a composite good produced with a continuum of differentiated goods $c_{t}^{i}$ via the Dixit-Stiglitz consumption basket of household $i$ :

$$
c_{t}^{i}=\left[\int_{0}^{1} c(z)_{t}^{\frac{\eta-1}{\eta}} d z\right]^{\frac{\eta}{\eta-1}}
$$

where $\eta>1$ denotes the elasticity of substitution across different varieties of goods. The set of demand equations is:

$$
c(z)_{t}=\left(\frac{P(z)_{t}}{P_{t}}\right)^{-\eta} c_{t}
$$

where 


$$
P_{t}=\left(\int_{0}^{1} p(z)_{t}^{(1-\eta)} d z\right)^{\frac{1}{1-\eta}}
$$

defines the aggregate price consumption index.

\subsection{Labour market structure}

It is assumed a continuum of differentiated labour inputs indexed by $j, j \in$ $[0,1]$. Following Schmitt-Grohé and Uribe (2005), household $i$ supplies all labour inputs. Moreover, as it is a common practice in the literature on LAMP in DSGE models, for sake of tractability, we assume that the labor supplies of the two households groups are perfect substitutes in production (Galì et al., 2004, 2007; Bilbiie, 2008; Colciago, 2011; Furlanetto and Seneca, 2012 ;Motta and Tirelli, 2012 and 2013). This assumption is not realistic, but is consistent with the stilized fact that wage dispersion does not seem to exhibit much variation at business cycle frequencies (Krueger et al. 2010; Heathcote et al. 2010; Maestri and Roventini, 2012). Further, dynamics that typically arise in LAMP models are determined by the profit margins variations associated to changes in real wages earned by RT consumers. By contrast, cyclical variations in real wages earned by Ricardian households are entirely offset by the corresponding changes in profit margins. In this regard, our results should survive richer labor market characterizations, such as in Lansing and Markiewicz (2013) who

allow for capital-skill complementarity, where the Ricardian agents are viewed as skilled whereas RT households are not. One related issue is that the two households groups might supply different amounts of labor at the given wage 
rate. Under a fiscal consolidation this would imply that consumption differences would be partly substituted with leisure differences.

Labor type-specific unions indexed by $j \in[0,1]$ have some monopoly power in the labour market and make wage-setting decisions. Given the wage $W_{t}^{j}$ fixed by union $j$, households are assumed to supply enough labour $h_{t}^{j}$ to satisfy demand. That is,

$$
h_{t}^{j}=\left(\frac{W_{t}^{j}}{W_{t}}\right)^{-\eta_{w}} h_{t}^{d}
$$

where $\eta_{w}>1$ is the elasticity of substitution across different labour inputs, $h_{t}^{d}$ is the aggregate labour demand and $W_{t}=\left(\int_{0}^{1}\left(W_{t}^{j}\right)^{\left(1-\eta_{w}\right)} d j\right)^{\frac{1}{\left(1-\eta_{w}\right)}}$ is the aggregate wage index. As in Galì (2007), it is assumed that the fraction of Ricardian and non-Ricardian households is uniformly distributed across unions and the aggregate demand for each labor type is uniformly distributed across households. Therefore optimizers and rule of thumbers work for the same amount of time. The labour supply, which is common across households, must satisfy the resource constraint $h_{t}^{s}=\int_{0}^{1} h_{t}^{j} d j$. Combining the latter with the labor demand equation we get:

$$
h_{t}^{s}=h_{t}^{d} \int_{0}^{1}\left(\frac{W_{t}^{j}}{W_{t}}\right)^{-\eta_{w}} d j
$$

\subsection{Ricardian Households}

Ricardian households have access to market for physical capital and to contingent nominal assets. In each period asset holders can purchase state-contingent nominal payment $X_{t+1}$ in period $t+1$ at the cost $E_{t} r_{t, t+1} X_{t+1}$ where $r_{t, t+1}$ is a 
stochastical discount factor between periods $t$ and $t+1$. Moreover, optimizing households must pay taxes on labor income and capital, respectively denoted as $\tau_{t}^{h}$ and $\tau_{t}^{k}$. However, a tax allowance is in place for depreciation.

Therefore, the ricardian household's period by period budget constraint in real terms reads as:

$$
\begin{gathered}
E_{t} r_{t, t+1} x_{t+1}+c_{t}^{o}+i_{t}^{o}=\frac{x_{t}}{\pi_{t}}+\left(1-\tau_{t}^{k}\right)\left[r_{t}^{k} u_{t}-a\left(u_{t}\right)\right] K_{t}^{o}+ \\
\quad+\tau_{t}^{k} q_{t} \delta K_{t}^{o}++\left(1-\tau_{t}^{h}\right) h_{t}^{d} \int_{0}^{1} w_{t}^{j}\left(\frac{w_{t}^{j}}{w_{t}}\right)^{-\eta_{w}} d j+d_{t}^{o}
\end{gathered}
$$

where $\frac{x_{t}}{\pi_{t}} \equiv \frac{X_{t}}{P_{t}}$ is the real payoff in period $t$ of the nominal state contingent assets purchased at $t-1$. $i_{t}^{o}$ denotes the real purchases investment goods at time t.

It is assumed that Ricardian households own physical capital $K_{t}^{o}$, accumulate it and then rent it out the firms at a real interest rate $r_{t}^{k}$. Moreover, the optimizers can control the intensity $u_{t}$ at which the capital is utilized. Hence, the cost of capital depends upon the degree of utilization $a\left(u_{t}\right)$ and it is defined as $a\left(u_{t}\right)=\gamma_{1}\left(u_{t}-1\right)+\frac{\gamma_{2}}{2}\left(u_{t}-1\right)^{2}$. Following CEE (2005) the function satisfies $a(1)=0$ and $a^{\prime}(1), a^{\prime \prime}(1)>0$. Ricardian households also receive firms dividends, $d_{t}^{o}$, and returns from financing the working capital of firms ${ }^{15}, d_{t}^{W H}$.

\footnotetext{
${ }^{15}$ Here we implicitly follow the financial sector characterization adopted in CEE 2005, who assume that a financial intermediary collects money balances from Ricardian households and from the Central Bank. Such funds are then used to finance the working capital needs of firms, and what is left returns to ricardian huseholds. Given that the Central Bank follows an interest rate policy, explicit modelling of the money market is unnecessary.
} 
The gross rate of inflation is $\pi_{t} \equiv \frac{P_{t}}{P_{t-1}}$.

The capital stock evolves according to the following law of motion:

$$
K_{t+1}^{o}=(1-\delta) K_{t}^{o}+i_{t}^{o}\left[1-S\left(\frac{i_{t}^{o}}{i_{t-1}^{o}}\right)\right]
$$

where $\delta$ is the deprecion rate of capital. The function $S$ introduces the adjustment costs on investment and satisfies the following properties: $S(1)=S^{\prime}(1)=$ $0, S^{\prime \prime}(1)>0$.

Hence, the Lagrangean reads as:

$$
L=E_{t} \sum_{s=0}^{\infty}\left\{+\lambda_{t+s}^{o}\left[\begin{array}{c}
U\left(c_{t+s}^{o}(i)-b c_{t+s-1}^{o} ; h_{t+s}(i)\right)+ \\
\frac{x_{t+s}}{\pi_{t+s}}+\left(1-\tau_{t+s}^{k}\right)\left[r_{t+s}^{k} u_{t+s}-a\left(u_{t+s}\right)\right] K_{t+s}^{o}+ \\
+\tau_{t+s}^{k} q_{t+s} \delta K_{t+s}^{o}+ \\
+\left(1-\tau_{t+s}^{h}\right) h_{t+s}^{d} \int_{0}^{1} w_{t+s}^{j}\left(\frac{w_{t+s}^{j}}{w_{t+s}}\right)^{-\eta_{w}} d j+ \\
+d_{t+s}^{o}-R_{t+s, t+s+1} x_{t+s+1}-c_{t+s}^{o}-i_{t+s}^{o}
\end{array}\right]+\right\}
$$

The Ricardian household's first order conditions with respect to $c_{t}^{o}, x_{t+1}$, $K_{t}^{o}, i_{t}^{o}$, and $u_{t}$ are respectively:

$$
\begin{gathered}
\frac{1}{c_{t}^{o}-b c_{t-1}^{o}}-\frac{b \beta}{c_{t+1}^{o}-b c_{t}^{o}}=\lambda_{t}^{o} \\
\lambda_{t}^{o}=\beta R_{t, t+1} \frac{\lambda_{t+1}^{o}}{\pi_{t+1}}
\end{gathered}
$$




$$
\begin{aligned}
\lambda_{t}^{o} q_{t}= & {\left[\beta E_{t} \lambda_{t+1}^{o}\left(1-\tau_{t+1}^{k}\right)\left[r_{t+1}^{k} u_{t+1}-a\left(u_{t+1}\right)\right]+\right.} \\
& \left.+q_{t+1}(1-\delta)+\delta q_{t+1} \tau_{t+1}^{k}\right]
\end{aligned}
$$

$$
\begin{aligned}
\lambda_{t}^{o}= & q_{t} \lambda_{t}^{o}\left[1-S\left(\frac{i_{t}^{o}}{i_{t-1}^{o}}\right)-\left[S_{i}\left(\frac{i_{t}^{o}}{i_{t-1}^{o}}\right)\right] i_{t}^{o}\right]+ \\
& -\beta q_{t+1} \lambda_{t+1}^{o} S_{i}\left(\frac{i_{t+1}^{o}}{i_{t}^{o}}\right) i_{t+1}^{o}
\end{aligned}
$$

$$
a_{u}\left(u_{t}\right)=r_{t}^{k}
$$

Following CEE (2005), the adjustment cost function is given by:

$$
S\left(\frac{i_{t}}{i_{t-1}}\right)=\frac{k}{2}\left(\frac{i_{t}}{i_{t-1}}-1\right)^{2}
$$

\subsection{Rule of thumb households}

As pointed out above, Non-Ricardian agents just consume current labor income because they cannot save neither invest. Since they don't have access to capital markets, they only pay taxes on labor income and receive transfers from the government.

Therefore: 


$$
c_{t}^{r t}=w_{t} h_{t}^{d}\left(1-\tau_{t}^{h}\right)+T R_{t}^{r t}
$$

The marginal utility of consumption for rule of thumbers is

$$
\lambda_{t}^{r t}=\frac{1}{c_{t}^{r t}-b c_{t-1}^{r t}}-\frac{b \beta}{c_{t+1}^{r t}-b c_{t}^{r t}}
$$

\subsection{Wage Setting}

In this model wages are set according to the Calvo (1983) framework. In particular each period a union faces a constant probability $\left(1-\alpha_{w}\right)$ of being able to reoptimize wages. In other words, $\alpha_{w}$ denotes the degree of wage stickiness. The unions which are not able to reoptimize the wage index it to a geometric average of past inflation and steady-state inflation according to the following rule:

$$
W_{t}^{j}=W_{t-1}^{j}\left(\frac{P_{t-1}}{P_{t-2}}\right)^{\chi_{w}} \pi^{\left(1-\chi_{w}\right)}=W_{t-1}^{j} \pi_{t-1}^{\chi_{w}} \pi^{\left(1-\chi_{w}\right)}
$$

where the parameter $\chi_{w} \in[0,1]$ is the indexation parameter.

Unions, in choosing the optimal wage $w_{t}^{*}$, have to take into account that they might not be able to do the same after $s$ periods. If this is the case, taking into account that all unions resetting at time $t$ choose the same wage, the real wage at the generic period $t+s$ will be:

$$
w_{t+s}=w_{t}^{*} \prod_{k=1}^{s} \frac{\pi_{t+k-1}^{\chi_{w}} \pi^{\left(1-\chi_{w}\right)}}{\pi_{t+k}}
$$


Hence, to derive the households' first order conditions with respect to the optimal wage, it is possible to pull out the part of the Lagrangean which is useful for this purpose. In particular, a weighted average of the two households types utility function is maximized by the optimizing union which will take into account of not being able to reoptimize in the future. Therefore the union objective is:

$E_{t} \sum_{s=0}^{\infty}\left(\beta \alpha_{w}\right)^{s}\left\{\begin{array}{c}\lambda_{t+s}\left[\left(1-\tau_{t+s}^{h}\right) h_{t+s}^{d} w_{t+s}^{\eta_{w}}\left(w_{t}^{*} \prod_{k=1}^{s} \frac{\pi_{t+k-1}^{\chi_{w}} \pi^{\left(1-\chi_{w}\right)}}{\pi_{t+k}}\right)^{\left(1-\eta_{w}\right)}\right]+ \\ -\lambda_{t+s}\left[\left(1-\tau_{t+s}^{h}\right) h_{t+s}^{d} w_{t+s}^{\left(1+\eta_{w}\right)}\left(w_{t}^{*} \prod_{k=1}^{s} \frac{\pi_{t+k-1}^{\chi_{w} \pi^{\left(1-\chi_{w}\right)}}}{\pi_{t+k}}\right)^{\left(-\eta_{w}\right)}\right]\end{array}\right\}$

where

$$
\lambda_{t+s}=\left[(1-\Omega) \lambda_{t+s}^{o}+\Omega \lambda_{t+s}^{r t}\right]
$$

is the average marginal utility between the Ricardian and non Ricardian's marginal utilities.

The first order condition with respect to the optimal wage is:

$$
\begin{gathered}
E_{t} \sum_{s=0}^{\infty}\left(\beta \alpha_{w}\right)^{s} h_{t+s}^{d}\left(\frac{w_{t}^{*}}{w_{t+s}}\right)^{\left(-\eta_{w}\right)}\left(\prod_{k=1}^{s} \frac{\pi_{t+k-1}^{\chi_{w}} \pi^{\left(1-\chi_{w}\right)}}{\pi_{t+k}}\right)^{\left(-\eta_{w}\right)} \lambda_{t+s} \times \\
\quad \times\left\{\begin{array}{c}
\frac{\left(\eta_{w}-1\right)}{\eta_{w}}\left(1-\tau_{t+s}^{h}\right) w_{t}^{*}\left(\prod_{k=1}^{s} \frac{\pi_{t+k-1}^{\chi_{w}} \pi^{\left(1-\chi_{w}\right)}}{\pi_{t+k}}\right)+ \\
+\frac{U_{n_{t+s}}}{\lambda_{t+s}}
\end{array}\right\}=0
\end{gathered}
$$


The term $\frac{\left(\eta_{w}-1\right)}{\eta_{w}}$ is the markup that would prevail in absence of wage stickiness $^{16}$.

It's now convenient to write the wage setting equation in recursive form by defining:

$$
\begin{aligned}
f_{1_{t}} \equiv & {\left[\frac{\left(\eta_{w}-1\right)}{\eta_{w}} w_{t}^{*} E_{t} \sum_{s=0}^{\infty}\left(\beta \alpha_{w}\right)^{s} h_{t+s}^{d}\left(\frac{w_{t}^{*}}{w_{t+s}}\right)^{\left(-\eta_{w}\right)}\right.} \\
& \left.\lambda_{t+s}\left(1-\tau_{t+s}^{h}\right)\left(\prod_{k=1}^{s} \frac{\pi_{t+k-1}^{\chi_{w}} \pi^{\left(1-\chi_{w}\right)}}{\pi_{t+k}}\right)^{\left(1-\eta_{w}\right)}\right]
\end{aligned}
$$

and

$$
f_{2_{t}} \equiv-w_{t}^{*\left(-\eta_{w}\right)} E_{t} \sum_{s=0}^{\infty}\left(\beta \alpha_{w}\right)^{s} h_{t+s}^{d} w_{t+s}^{\eta_{w}} U_{n_{t+s}}\left(\prod_{k=1}^{s} \frac{\pi_{t+k-1}^{\chi_{w}} \pi^{\left(1-\chi_{w}\right)}}{\pi_{t+k}}\right)^{\left(-\eta_{w}\right)}
$$

In recursive form:

$$
\begin{aligned}
f_{1_{t}}= & \frac{\left(\eta_{w}-1\right)}{\eta_{w}} w_{t}^{*} h_{t}^{d}\left(1-\tau_{t}^{h}\right)\left(\frac{w_{t}}{w_{t}^{*}}\right)^{\left(\eta_{w}\right)} \lambda_{t}+ \\
& +\beta \alpha_{w} E_{t}\left(\frac{w_{t+1}^{*}}{w_{t}^{*}}\right)^{\left(\eta_{w}-1\right)}\left(\frac{\pi_{t}^{\chi_{w}} \pi^{\left(1-\chi_{w}\right)}}{\pi_{t+1}}\right)^{\left(1-\eta_{w}\right)} f_{1_{t+1}}
\end{aligned}
$$

and

\footnotetext{
${ }^{16}$ In the deterministic steady state it also denotes the wage murkup in absence of trend inflation or in case of full indexation (this is the case in this paper).
} 


$$
f_{2_{t}}=-\left(\frac{w_{t}}{w_{t}^{*}}\right)^{\left(\eta_{w}\right)} h_{t}^{d} U_{n_{t}}+\beta \alpha_{w} E_{t}\left(\frac{w_{t+1}^{*}}{w_{t}^{*}}\right)^{\left(\eta_{w}\right)}\left(\frac{\pi_{t}^{\chi_{w}} \pi^{\left(1-\chi_{w}\right)}}{\pi_{t+1}}\right)^{\left(-\eta_{w}\right)} f_{2_{t+1}}
$$

Hence, the wage setting equation reads as:

$$
f_{1_{t}}=f_{2_{t}}
$$

\subsection{Firms}

Intermediate firms compete monopolistically by producing good $z$ according to the following technology:

$$
y_{t}(z)=\left(K_{t}(z)\right)^{\vartheta}\left(h_{t}(z)\right)^{(1-\vartheta)}
$$

where $K_{t}(z)$ is the physical capital stock that firms rent by Ricardian households and $h_{t}(z)$ is the labor input used by each firm $z$. In particular it is defined as:

$$
h_{t}(z)=\left(\int_{0}^{1}\left(h_{t}^{j}(z)\right)^{\frac{\eta_{w}-1}{\eta_{w}}} d j\right)^{\frac{\eta_{w}}{\eta_{w}-1}}
$$

Firms must pay the wage bill in advance of the production. In other words they are subject to a cash in advance constraint of the form:

$$
m_{z t}^{f}=\nu w_{t} h_{z t}
$$

where $m_{z t}^{f}$ denotes the real money balances by firm $z$ and $\nu$ is the fraction of 
wage which is payed in advance. The wage is lent by Ricardian households which at the end of the period receive back money at the gross nominal interest rate.

Therefore the marginal costs the firms have to face reads as:

$$
m c_{t}=\left(\frac{r_{t}^{k}}{\vartheta}\right)^{\vartheta} w_{t}\left[1+\nu\left(1-\frac{1}{R}\right)\right]
$$

\subsection{Price Setting}

As for wages, prices are set according to the Calvo (1983) framework. In each period a firm faces a constant probability $(1-\alpha)$ of being able to re-optimize prices. Non re-optimizing firms index their price to a geometric average of past inflation and steady-state inflation:

$$
P_{t}(z)=P_{t-1}(z)\left(\frac{P_{t-1}}{P_{t-2}}\right)^{\chi} \pi^{(1-\chi)}=P_{t-1}(z) \pi_{t-1}^{\chi} \pi^{(1-\chi)} .
$$

The optimal price $P_{t}^{*}$ is chosen in order to maximize the discounted value of expected future profits. Moreover, it's important to remind here that only Ricardian households own firms. Hence, the firms' maximization problem is:

$$
\begin{aligned}
& \max _{P_{t}^{*}} E_{t} \sum_{s=0}^{\infty}(\beta \alpha)^{s} \frac{P_{t}}{\lambda_{t}^{o}} \frac{\lambda_{t+s}^{o}}{P_{t+s}}\left(P_{t}^{*} \prod_{k=1}^{s} \pi_{t+k-1}^{\chi} \pi^{(1-\chi)}-P_{t+s} m c_{t+s}\right) y_{t, t+s}(z) \\
& \text { subject to: }
\end{aligned}
$$




$$
y_{t, t+s}(z)=\left(\frac{P_{t}^{*} \prod_{k=1}^{s} \pi_{t+k-1}^{\chi} \pi^{(1-\chi)}}{P_{t+s}}\right)^{(-\eta)} y_{t+s}^{d}
$$

where $y_{t}^{d}$ is the aggregate demand and $\frac{\lambda_{t+s}^{o}}{\lambda_{t}^{o}}$ denotes the stochastic discount factor of Ricardian households.

The first order condition with respect to $P_{t}^{*}$ is:

$E_{t} \sum_{s=0}^{\infty}(\beta \alpha)^{s} \frac{\lambda_{t+s}^{o}}{\lambda_{t}^{o}}\left(\frac{\prod_{k=1}^{s} \pi_{t+k-1}^{\chi} \pi^{(1-\chi)}}{\prod_{k=1}^{s} \pi_{t+k}}\right)^{(-\eta)} y_{t+s}^{d}\left(\frac{P_{t}^{*}}{P_{t}}\right)^{(-\eta-1)}\left[\begin{array}{c}\left(\frac{P_{t}^{*}}{P_{t}}\right)\left(\frac{\prod_{k=1}^{s} \pi_{t+k-1}^{\chi} \pi^{(1-\chi)}}{\prod_{k=1}^{s} \pi_{t+k}}\right)+ \\ +\frac{\eta}{(1-\eta)} m c_{t+s}\end{array}\right]=0$

The term $\frac{(\eta-1)}{\eta}$ is the markup which would prevail in absence of price stickiness $^{17}$.

It's useful to write the price setting equation in recursive form by defining:

$$
x_{1_{t}} \equiv\left(\frac{P_{t}^{*}}{P_{t}}\right)^{(-\eta-1)} E_{t} \sum_{s=0}^{\infty}(\beta \alpha)^{s} \frac{\lambda_{t+s}^{o}}{\lambda_{t}^{o}}\left(\frac{\prod_{k=1}^{s} \pi_{t+k-1}^{\chi} \pi^{(1-\chi)}}{\prod_{k=1}^{s} \pi_{t+k}}\right)^{(-\eta)} y_{t+s}^{d} m c_{t+s}
$$

and

\footnotetext{
${ }^{17}$ In the deterministic steady state it also denotes the price murkup in absence of trend inflation or in case of full indexation.
} 


$$
x_{2_{t}} \equiv\left(\frac{P_{t}^{*}}{P_{t}}\right)^{(-\eta)} E_{t} \sum_{s=0}^{\infty}(\beta \alpha)^{s} \frac{\lambda_{t+s}^{o}}{\lambda_{t}^{o}}\left(\frac{\prod_{k=1}^{s} \pi_{t+k-1}^{\chi} \pi^{(1-\chi)}}{\prod_{k=1}^{s} \pi_{t+k}}\right)^{(1-\eta)} y_{t+s}^{d}
$$

By writing recursively:

$$
x_{1_{t}}=p_{t}^{*(-\eta-1)} y_{t}^{d} m c_{t}+E_{t}\left\{(\beta \alpha) \frac{\lambda_{t+1}^{o}}{\lambda_{t}^{o}}\left(\frac{\pi_{t}^{\chi} \pi^{(1-\chi)}}{\pi_{t+1}}\right)^{(-\eta)}\left(\frac{p_{t}^{*}}{p_{t+1}^{*}}\right)^{(-\eta-1)} x_{1_{t+1}}\right\}
$$

and

$$
x_{2_{t}}=p_{t}^{*(-\eta)} y_{t}^{d}+E_{t}\left\{(\beta \alpha) \frac{\lambda_{t+1}^{o}}{\lambda_{t}^{o}}\left(\frac{\pi_{t}^{\chi} \pi^{(1-\chi)}}{\pi_{t+1}}\right)^{(1-\eta)}\left(\frac{p_{t}^{*}}{p_{t+1}^{*}}\right)^{(-\eta)} x_{2_{t+1}}\right\}
$$

It's possible to rewrite the price setting equation as:

$$
x_{2_{t}}=\frac{\eta}{\eta-1} x_{1_{t}}
$$

\subsection{Aggregation}

The aggregate production function is:

$$
y_{t}=\left(u_{t} K_{t}\right)^{\vartheta} h_{t}^{d(1-\vartheta)}
$$

and the aggregate absortion is: 


$$
y_{t}^{d}=c_{t}+i_{t}+g_{t}+a\left(u_{t}\right) K_{t}
$$

where:

$$
\begin{gathered}
c_{t}=(1-\Omega) c_{t}^{o}+\Omega c_{t}^{r t} \\
i_{t}=(1-\Omega) i_{t}^{o} \\
K_{t}=(1-\Omega) K_{t}^{o}
\end{gathered}
$$

As for transfers:

$$
T R_{t}=\Omega T R_{t}^{r t}
$$

given that by assumption transfers are assigned to RT consumers only .

\subsection{Market clearing}

\subsubsection{Goods market equlibrium}

The expression warranting the equilibrium in the good market is:

$$
y_{t}=s_{t} y_{t}^{d}
$$


where $s_{t}$ denotes the resource cost due to relative price dispersion in the Calvo model. It evolves according to:

$$
s_{t}=(1-\alpha) p_{t}^{*(-\eta)}+\alpha\left(\frac{\pi_{t}}{\pi_{t-1}^{\chi} \pi^{(1-\chi)}}\right)^{\eta} s_{t-1}
$$

where $p_{t}^{*}$, in the light of the aggregate price index, must satisfy:

$$
\alpha \pi_{t}^{(\eta-1)}\left(\pi_{t-1}^{\chi} \pi^{(1-\chi)}\right)^{(1-\eta)}+(1-\alpha) p_{t}^{*(1-\eta)}=1
$$

\subsubsection{Labour market equilibrium}

The equilibrium on the labour market is given by:

$$
h_{t}^{s}=\widetilde{s}_{t} h_{t}^{d}
$$

where $\widetilde{s}_{t}$ denotes the resource cost due to relative wage dispersion in the Calvo model. It evolves according to:

$$
\widetilde{s}_{t}=\left(1-\alpha_{w}\right)\left(\frac{w_{t}^{*}}{w_{t}}\right)^{\left(-\eta_{w}\right)}+\alpha_{w}\left(\frac{w_{t-1}}{w_{t}}\right)^{\left(-\eta_{w}\right)}\left(\frac{\pi_{t}}{\pi_{t-1}^{\chi_{w}} \pi^{\left(1-\chi_{w}\right)}}\right)^{\eta_{w}} \widetilde{s}_{t-1}
$$

where it must hold that:

$$
w_{t}^{*}=\left(\frac{w_{t}^{\left(1-\eta_{w}\right)}-\alpha_{w} w_{t-1}^{\left(1-\eta_{w}\right)}\left(\frac{\pi_{t-1}^{\chi_{w} \pi^{\left(1-\chi_{w}\right)}}}{\pi_{t}}\right)^{\left(1-\eta_{w}\right)}}{\left(1-\alpha_{w}\right)}\right)^{\frac{1}{\left(1-\eta_{w}\right)}}
$$




\subsection{Fiscal Authority}

The government budget constraint in nominal tems reads as:

$$
P_{t} G_{t}+P_{t} T R_{t}+B_{t}=P_{t} \tau_{t}^{k}\left[r_{t}^{k} u_{t}-a\left(u_{t}\right)-q_{t} \delta\right] K_{t}+P_{t} \tau_{t}^{h} w_{t} h_{t}+V_{t} B_{t+1}
$$

where $B_{t}$ is the number of 1 period bonds issued at time $t-1$, where reimbursement at maturity is 1 dollar. $V_{t}$ is the dollar price at which the bond is sold at time $t$. The gross interest rate is $R_{t}=\frac{1}{V_{t}}$.

Rewriting the government budget constraint:

$P_{t} G_{t}+P_{t} T R_{t}+B_{t}=P_{t} \tau_{t}^{k}\left[r_{t}^{k} u_{t}-a\left(u_{t}\right)-q_{t} \delta\right] K_{t}+P_{t} \tau_{t}^{h} w_{t} h_{t}+\frac{1}{R_{t}} B_{t+1}$

Dividing for $P_{t}$ :

$$
G_{t}+T R_{t}+\frac{B_{t}}{P_{t}}=\tau_{t}^{k}\left[r_{t}^{k} u_{t}-a\left(u_{t}\right)-q_{t} \delta\right] K_{t}+\tau_{t}^{h} w_{t} h_{t}+\frac{1}{R_{t}} \frac{B_{t+1}}{P_{t}}
$$

Let's multiply and divide $\frac{B_{t}}{P_{t}}$ for $\frac{P_{t-1}}{P_{t-1}}$ :

$G_{t}+T R_{t}+1 * \frac{B_{t}}{P_{t}} \frac{P_{t-1}}{P_{t-1}}=\tau_{t}^{k}\left[r_{t}^{k} u_{t}-a\left(u_{t}\right)-q_{t} \delta\right] K_{t}+\tau_{t}^{h} w_{t} h_{t}+\frac{1}{R_{t}} \frac{B_{t+1}}{P_{t}}$

Hence:

$$
G_{t}+T R_{t}+\frac{b_{t}}{\pi_{t}}=\tau_{t}^{k}\left[r_{t}^{k} u_{t}-a\left(u_{t}\right)-q_{t} \delta\right] K_{t}+\tau_{t}^{h} w_{t} h_{t}+\frac{b_{t+1}}{R_{t}}
$$


where $b_{t}=\frac{B_{t}}{P_{t-1}}$ is the real rembursement value of debt.

\subsection{Monetary Authority}

Monetary authority adjusts the nominal interest rate according to the following rule:

$$
\left(\frac{R_{t}}{R_{t}^{* *}}\right)=\left(\frac{\pi_{t}}{\pi^{* *}}\right)^{\phi_{\pi}}\left(\frac{y_{t}}{y^{* *}}\right)^{\phi_{y}}
$$

\section{Appendix C: The Welfare-Based Ratio and the Consumption Equivalent Measure}

The Welfare-Based ratio measure described here, follows Ascari and Ropele (2012).

Define $V_{0}^{J}$ and $V_{\text {old }}^{J}$ as the expected values of B1, respectively at time zero (when consolidation experiment is actually implemented) and at the initial steady state (before the consolidation experiment). $j=o, r t$ refers to optimizing and RT consumers respectively.

Determining $V_{o l d}^{J}$ is straighforward:

$$
V_{\text {old }}^{J}=\frac{1}{(1-\beta)}\left[\ln (1-b) C_{\text {old }}^{J}-\frac{\phi_{1}}{(1+\phi)}\left(h s_{\text {old }}^{J}\right)^{(1+\phi)}+\xi \ln G_{\text {old }}\right]
$$

where $C_{\text {old }}^{J}, h s_{\text {old }}^{J}$ and $G_{\text {old }}$ are respectively the pre-consolidation steady state values of consumption, hours and government spending. Obtaining the solution 
for $V_{0}^{J}$ requires numerical simulations as it accounts for both the new steady state and for the transition phase.

Following Ascari and Ropele (2012) $V_{\text {old }}^{J}$ and $V_{0}^{J}$ allow to compute the welfare-based ratio, $W R$ :

$$
W R^{J}=-\left(\frac{V_{0}^{J}-V_{\text {old }}^{J}}{b_{y, \text { old }}^{*}-b_{y, \text { new }}^{*}}\right)
$$

where the denominator $b_{y, \text { old }}^{*}-b_{y, \text { new }}^{*}$ allows to weigh the welfare change by the size of debt reduction.

Since the utility function is not cardinal, the numerator of the ratio must be transformed in a measure which can "quantify" the welfare cost (or gain) of fiscal consolidation. This is obtained computing the consumption equivalent measure which is defined as the fraction of consumption that households must give up to permanently reduce debt. The consumption equivalent measure reads as:

$$
\gamma^{J}=1-\exp \left[(1-\beta)\left(V_{0}^{J}-V_{\text {old }}^{J}\right)\right]
$$

and the welfare-based ratio is:

$$
W R^{J}=\left(\frac{\gamma^{J}}{b_{y, \text { old }}^{*}-b_{y, \text { new }}^{*}}\right)
$$

Since $\gamma^{J}$ denotes a welfare cost, fiscal consolidation is welfare improving when the welfare-based ratio is negative. 
To disentangle the welfare effects of consolidation during the transition dynamics from its the long-run welfare gains, let's define the long-run costs in terms of consumption equivalent units as:

$$
\gamma_{\text {long_run }}^{J}=1-\exp \left[(1-\beta)\left(V_{\text {new }}^{J}-V_{\text {old }}^{J}\right)\right]
$$

where $V_{\text {old }}^{J}$ and $V_{\text {new }}^{J}$ are respectively the value fuctions associated to the old and new steady-state debt ratios. Hence the long-run welfare-based ratio is:

$$
W R_{\text {long_run }}^{J}=\left(\frac{\gamma_{\text {long_run }}^{J}}{b_{y, \text { old }}^{*}-b_{y, \text { new }}^{*}}\right)
$$

The short-run welfare-based ratio is then:

$$
W R_{\text {short_run }}^{J}=W R^{J}-W R_{\text {long_run }}^{J}
$$

